
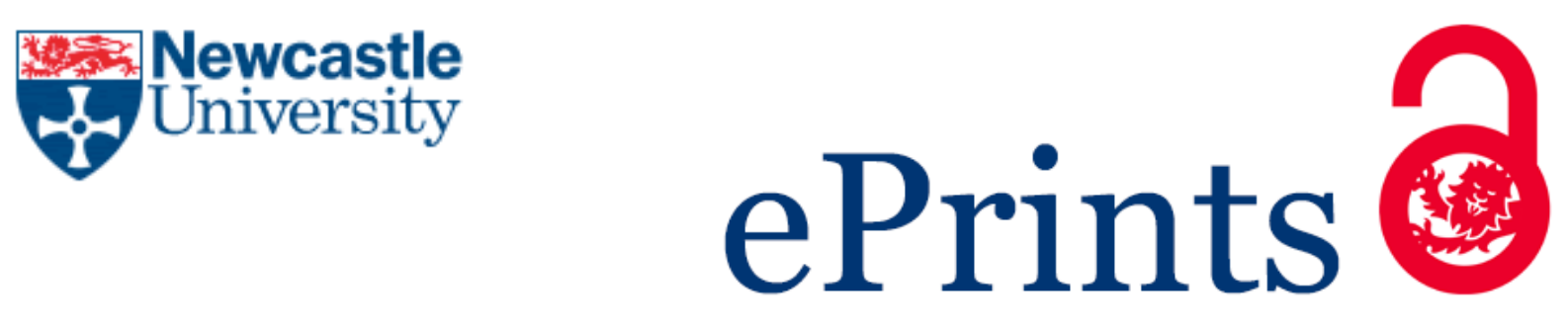

Lin Z, Filieri R. Airline passengers' continuance intention towards online check-in services: The role of personal innovativeness and subjective knowledge. Transportation Research Part E: Logistics and Transportation Review 2015, 81, 158-168.

Copyright:

(C) 2015. This manuscript version is made available under the CC-BY-NC-ND 4.0 license

DOI link to article:

http://dx.doi.org/10.1016/i.tre.2015.07.001

Date deposited:

$26 / 04 / 2016$

Embargo release date:

24 July 2018

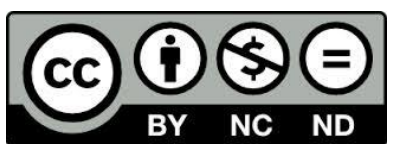

This work is licensed under a

Creative Commons Attribution-NonCommercial-NoDerivatives 4.0 International licence 


\title{
Airline passengers' continuance intention towards online check-in services: The role of personal innovativeness and subjective knowledge
}

\begin{abstract}
This study integrates the individual psychology constructs (personal innovativeness and subjective knowledge) to the Technology Acceptance Model to develop and test a model of passengers' continuance intention towards online flight check-in services. Predictions were tested with data from a sample of airline passengers in China who have experienced the online check-in service. The findings of this study demonstrate that airline passengers' innovativeness and subjective knowledge have a direct effect on continuance intention, and an indirect effect through partial mediation of perceived ease of use and perceived usefulness. Theoretical and managerial implications are discussed.
\end{abstract}

Keywords: Technology-based self-services check-in; personal innovativeness; subjective knowledge; Technology Acceptance Model; airline passenger. 


\section{Introduction}

Firms in the transport industries are increasingly using information and communication technology (ICT) for delivering services and creating competitive advantage (Álvarez et al. 2007; Park and Gretzel 2007; Tanford et al. 2012). Online self-service technologies are a particular type of internet-based ICT that customers independently use without any interaction with, or assistance from employees (e.g. Curran and Meuter 2005; Meuter et al. 2000). Successful online self-services help transport firms to standardize service delivery, reduce labor costs, and expand the options for service delivery. There has been a surge of online selfservices in the transport industries, including services such as online ticket booking, online check-in services; online live services updates, and the like (Lu et al. 2009). With the popularity of mobile internet services, these functions are now available through smartphones(Lu et al. 2009). Self-service check-in (including web, kiosk and mobile phone-based) is one of key components of International Air Transport Association (IATA) Fast Travel Program. Online check-in According to IATA (2015a), the program provides more choice and more control for passengers, and lower costs for the industry with annual savings of up to US\$ 2.1 billion (IATA 2015). Around $75 \%$ of passengers worldwide want more self service options, yet the current penetration rate is only $21 \%$, while the broad target is $35 \%$ by the end of 2015 (IATA, 2015a). This is because-Motivating customers to use online self-services can be challenging because online self-services require customer's willingness to learn the new technology and additional resources to learn how to use them (Curran and Meuter 2005).

Lu et al. (2009) have investigated airline passenger intention to use airport self-service check-in kiosks and indicated that passenger behavior regarding the use of other self-service check-in options such as internet-based ones have not been well understood. Moreover, extant research into the diffusion of new technology has mainly focused on the initial adoption, 
ignoring what happens next (Wang et al. 2013). The process of innovation diffusion goes through six stages: awareness, investigation, evaluation, trial, repeated use, and commitment. As the process of innovation diffusion moves from initial trial, users' perceptions change over time as they gain more experiences of the technology (Karahanna et al. 1999; Lee et al. 2011). Thus, this research gap calls for future research to evaluate whether previous technology adoption models (e.g. TAM) can be adequate in explaining repeated use intention. However, little is known whether perceived ease of use (PEOU) and perceived usefulness (PU), namely two key TAM variables, can predict continuance intention.

This study has adopted the Technology Acceptance Model (TAM) for predicting user acceptance of new technologies (Davis 1989). TAM has been adopted because it has been widely adopted in research on technology acceptance mainly because of its parsimony and robustness (Plouffe et al. 2001; Lu et al. 2009); however, the model suggests little on continued use intention. Successful diffusion of a new technology in the transport industries depends on repeated usage of the new technology (Rogers 1995).

Additionally, scholars have suggested extending TAM in order to include more possible constructs that could better explain an individual's adoption behavior of technologies (Lu et al. 2009). Scholars suggest that psychological factors could explain technology adoption behaviors (e.g. Ajzen and Fishbein 1980; Lu et al. 2005). However, despite the growing importance of online self-services in the aviation industries, there has been little research on passengers' psychological factors and continuance of online self-services (e.g. Kokkinou and Cranage 2013). Accordingly, this study attempts to fill this gap by examining travelers' continuance intention of using online flight check in services. Drawing from psychology, personal innovativeness and self-perception of knowledge of a technology have been included in our model. Personal innovativeness is a personality trait that is critical for innovation 
diffusion (Rogers 1995) and is defined as the user's predisposition towards innovation across different products and services (Goldsmith and Hofacker 1991). Innovative individuals tend to seek new and stimulating experiences, they are eager to try new products earlier than their peers; and they tend to seek information before using the service, therefore, they might be more willing to try first and repeat the use of a new technology.

Moreover, self-concept is an influential factor that motivates people's behaviors (Myers and Twenge 2013). Self-perception of knowledge in the domain of technology use is one such factor which may determine individuals' intention to continue using the technology. An individual who believes to be knowledgeable about a new technology will be more confident about using the new technology and about repeating its use over time.

To summarize, in order to provide a better explanation of passengers' intention to continue the use of online check-in services, in our conceptual model we include two psychological constructs, namely subjective knowledge and personal innovativeness; and two TAM factors, i.e. PEOU and PU. The proposed model was tested by means of a web-based survey of members of a popular online passenger community in China who have experience of online check-in services. Partial least squares structural equation modeling (PLS-SEM) was adopted for data analysis. The paper is organized as follows. In the next section, we discuss the conceptual background for the research. In the subsequent sections, we present the research model and hypotheses, methodology, and results. Finally, the managerial and theoretical implications as well as the limitations and future research suggestions are discussed.

\section{Conceptual Background and Hypotheses}

\subsection{Psychological constructs: Personal innovativeness and Subjective Knowledge}


Personal innovativeness is a personality trait that refers to an individual's tendency to willingly embrace change and try new things (Chau and Hui 1998; Cotte and Wood 2004, Roehrich 2004; Thatcher and Perrewe 2002), which can be further defined at either global trait level, or domain-specific level (Hirunyawipada and Paswan 2006). Domain specific innovativeness is defined by the virtue of identifiable characteristics and actual acquisition of new information, ideas and products (Hirschman 1980; Midgley and Dowling 1978).

Studies of e-commerce and online booking of travel services (e.g. San Martín and Herrero 2012) usually adopt the definition of innovativeness in the domain of information technology (Agarwal and Prasad 1998). In contrast, this study adopts the definition at global trait level, because the personal innovativeness is a predisposition towards innovation across different products and services (Goldsmith and Hofacker 1991), and this global conception has been widely accepted in psychology to identify the innovative characteristics of individuals (Im et al. 2003). As a personality trait, personal innovativeness shapes individuals' perceptions of their capabilities (Thatcher and Perrewe 2002) to understand and apply complex technical knowledge, and to cope with the uncertainty of new technology (Rogers 1995). Given its generalized definition, personal innovativeness has also been termed as “innate innovativeness” (Hirschman 1980), or “innovative predisposition” (Midgley and Dowling 1978).

An individual's knowledge can be either subjective or objective (Brucks 1985; Flynn and Goldsmith 1999), the former pertains to an individual's perception of the amount of information about a product or service stored in his or her memory, while the latter refers to the actual amount of accurate information stored in his or her memory (Packard and Wooten 2013; Park et al. 1994). Subjective knowledge is a self-concept (Markus and Wurf 1987). Self-concept refers to the totality of the individual's thoughts and feelings having reference to 
himself as an object (Sirgy 1982, p. 287). Self-concept is an important contributor to global evaluations of the self (Marsh 1986; Tafarodi and Swann 1995), and self-evaluation is an important source of intrinsic motivation (Shamir et al. 1993). People are motivated to to perform activities that enhance their self-esteem while they try to maintain a consistent view of their self-concept over time (Sirgy 1982; Gecas 1982; Packard and Wooten 2013). Subjective knowledge as a self-concept interprets and organizes self-relevant actions and experiences, therefore it has motivational consequences on behavior (Markus and Wurf 1987; Myers and Twenge 2013). Both subjective knowledge (what we think we know) and objective knowledge (what we actually know) are partially the result of experiences, yet they are different constructs (Flynn and Goldsmith 1999), and have different effects on consumption behavior (Brucks 1985). Experience is associated more with subjective knowledge than objective knowledge, and subjective knowledge has a stronger influence on consumption behavior than objective knowledge (Packard and Wooten 2013). By accumulating experiences individuals develop a knowledge base on the new technology and on how to use it. This study thus focuses on airline passenger subjective knowledge, i.e. the perception or belief of one's own level of knowledge on online self-service, how to use it, and their level of expertise.

\section{Research Model and Hypotheses}

Individuals who possess the personality trait of innovativeness have greater willingness to experiment with new ideas, they are eager to try new products earlier than their peers, they tend to seek information before using the service, all of these make these consumers more knowledgeable than others on new technologies (Engel et al. 1969). Following recent studies on online shopping settings (e.g. Barrutia and Gilsanz 2013), we hypothesize that:

(H1) Personal innovativeness positively influences subjective knowledge. 
In the context of self-services, Meuter et al. (2005) suggested that consumers who view themselves as knowledgeable will be more self-confident of using self-services, will perceive the use of online self-services as easy, and will recognize more of the benefits associated with self-service use. Thus, we hypothesize:

(H2) Subjective knowledge positively influences the perceptions of ease of use (H2a) and usefulness (H2b).

As innovators love to try new things and are more knowledgeable about technologies than non-innovators, they are also more likely to perceive self-services as easy to use as well as to appreciate their usefulness (Cotte and Wood 2004; Roehrich 2004). Innovative individuals tend to be more risk-taking, which means that they will be more eager to try new technologies (Agarwal and Prasad 1998). Results on the role of innovativeness on PEOU and PU have been inconsistent. On the one hand, Agarwal and Karahanna (2000) found that personal innovativeness was not a significant predictor of PEOU and PU of the World Wide Web; on the other hand, Lu et al. (2005) in a study on adoption of wireless Internet services via mobile technology found that innovativeness had a strong influence on PEOU and PU. For a technology like online flight check-in innovative people. In line with Lu et al. (2005), we expect that an innovative individual is generally more curious about knowing the benefits emerging from adopting a new technology. Moreover, innovative people are more confident about their capability to handle and use a new technology, which should lower the perceived difficulty in using a new technology like online flight check-in. Thus, we hypothesize:

(H3) Personal innovativeness positively influences the perception of ease of use (H3a) and usefulness (H3b).

Previous studies have employed and extended the TAM to explain consumer intention 
to adopt self-services (Curran and Meuter 2005; Dabholkar 1996; Meuter et al. 2000;

Pikkarainen et al. 2004). For instance, Meuter et al. (2000) identified usefulness, ease of use, availability and convenience as important factors that lead to satisfaction or dissatisfaction with online self-services adoption. Dabholkar (1996) identified control, performance, ease of use, need for human interaction, reliability and speed as critical variables in the usage of online self-services. Pikkarainen et al. (2004) found that PU of information and amount of information on online banking influenced consumer acceptance of online self-services, while ease of use, enjoyment, and security and privacy did not affect online banking use. Lu et al. (2009) use TAM to investigate Taiwanese airline passengers' intention to use self-service kiosk check-in while considering additional factors such as external stimuli, perceived service quality, perceived behavioral control, need for service, and perceived risk. They found that although PEOU and PU are positively related to attitude towards technology use, they do not seem to predict behavioural intention to use the technology, whereas attitude and external stimuli were strong predictors of behavioral intentions to use the self-service check-in kiosks.

It appears that prior research has paid little attention to the influence that TAM factors play on the intention to repeat use after initial adoption of a new technology (Wang et al. 2013). This study aims to test whether the PEOU of a technology and its PU can explain consumers' continuance intention. Hence, we hypothesize:

(H4a) Perceived ease of use positively influences continuance intention.

(H4b) Perceived usefulness positively influences continuance intention.

Innovative consumers have the predisposition to try new technologies (Steenkamp et al. 1999), but it is not yet known whether they will continue using them after initial trial. Previous research suggests mixed results on the role of consumer innovativeness in the 
adoption of online self-services. For instance, Lassar et al. (2005) reveal that domain-specific consumer innovation significantly and positively affects the adoption of online banking, Lu et al. (2005) found that personal innovativeness does not significantly predict wireless internet service via mobile technology adoption, while Liljander et al. (2006) found that consumer (general) innovativeness had only a marginal effect on attitudes towards online or phone flight check-in, and Jackson et al. (2013) found that personal innovativeness had no influence on the intention to adopt e-commerce purchasing systems. In this study, we argue that innovative individuals will be eager to repeat a behavior once they have acknowledged the benefits provided by a specific technology. Moreover, they will also repeat the usage of a new technology in order to keep up with their lifestyle (how other see them) and with their selfimage concept. Therefore, we hypothesize:

(H5) Personal innovativeness positively influences continuance intention.

People are motivated to maintain consistency between self-concept and behavior (Gecas 1982). For example, previous research suggests that customers are more likely to choose products that match their perceived knowledge in that domain (Burson 2007, Moorman et al. 2004; Park et al. 1994). They are also motivated to maintain and enhance the sense of competence over time (Gecas 1982), therefore it is possible that customers will continue to use a technology if it matches their perceived level of knowledge. Klerck and Sweeney (2007) in a study on consumer consumption of genetically modified food found that subjective knowledge reduces psychological risk of the technology, which further influences the propensity to search for and buy genetically modified foods. After initial trial of a new technology, consumers can become more self-confident and knowledgeable about the technology, and continuing to use it enhances their self-concept of being knowledgeable. Moreover, the more they feel knowledgeable about a technology, the lower the perceived 
cognitive effort that is needed to use the technology again will be. Thus, we hypothesize as follows:

(H6) Subjective knowledge positively influences continuance intention.

Figure 1 depicts the research model with hypotheses for this study.

[Figure 1 about here]

\section{Methodology}

\subsection{Research setting}

Airlines were early adopters of information and communication technologies in comparison to many other travel and tourism businesses (Buhalis 2004). We selected China's airline market as the study's field context for several reasons. China's air transport market has been seen as the growth 'engine' for the global airline industry (IATA 2015b) and the country has one of the largest internet populations in the world. In 2013, it has an internet penetration rate of $45.8 \%$, with a total of over 618 million internet users, a growth of 9.5 percent over 2012, and the trend of growth continues thanks to the increasing popularity of mobile internet (CNNIC 2014). The 'Big Three' airlines in China (Air China, China Southern and China Eastern) all have online check-in facilities, including the use of smartphone for self check-in service. Passengers can now check-in online by logging in the airline's website through a computer or a smartphone, or using the airline's smartphone applications. Some companies even provide check-in facility for passengers through mobile application for online check-in service (e.g. China Southern uses Wechat, which has over 400 million users in China, CARNOC 2013).

\subsection{Sample and procedure}


Data were collected using online survey with a web-based questionnaire hosted by a commercial market research website (www.diaochapai.com). Online survey is especially suitable for this research as we investigate online service, and online surveys have been widely adopted in recent hospitality and tourism research (Ayeh et al. 2013). An invitation to participation to the study was sent to a convenience sample of airline users by means of a post advertised in a popular online air traveler community in China (bbs.feeyo.com). There are three reasons for adopting this approach. First, members of online traveler community are usually regular travelers and regular travelers are more qualified and competent to make informed judgment regarding airlines' services (Anderson et al. 2008), including online check-in facilities than infrequent travelers. From a managerial perspective, regular travelers have implications for the firm as a steady stream of revenue, critical for the survival and growth of airlines and other travel related companies such as hotels. Third, online traveler community is also a community of practice (Wasko and Faraj 2005), within which knowledge is created, stored and disseminated through members' information and experience sharing activities, essential for the diffusion of airline online self-services.

In order to focus only on customers who had previous experience with using the online check-in service, a screening question was set to confirm that respondents have used online check-in facility at least once in the last 12 months. As an incentive, participants were offered a summary of the results automatically generated by the survey hosting website at the end of the survey.

Questionnaire was first developed in English and then translated into Chinese by one of the researchers. To assure context validity, we asked six airline managers and two research colleagues in China to comment on the appropriateness of the wording of each item, and we further pre-tested the questionnaire with a small sample of members of online traveler 
community $(n=20)$ before launching the main survey. The Chinese final version of the questionnaire was translated back into English by an independent professional translator.

We received 264 usable responses. There was a total of 1015 visitors click through the link to the survey site, hence a response rate of $26 \%$, which is considered to be high percentage (Menachemi 2011). Table 1 presents the demographics of the sample. The sample was about equally split between male (47\%) and female (53\%). The majority respondents (58\%) were in the age bracket between 30 and 39 years old, and had a tertiary education qualification (76\%). They were mainly white-collar workers such as businesspersons (30\%) or professionals $(21 \%)$.

[Table 1 about here]

\subsection{Measures}

Innovativeness was measured using three items adapted from Goldsmith and Hofacker (1991). Subjective knowledge was measured with three items based on Flynn and Goldsmith (1999). Three items measuring perceived ease of use were adapted from Davis (1989), while PU was operationalized to fit the specific context of online flight check-in. Finally, the two items measuring continuance intention of online check-in were adapted from Blodgett et al. (1997). A five-point Likert-type scale was used for the measurement of the above constructs ( $1=$ strongly disagree; $5=$ strongly agree). The specific items measuring the latent constructs are presented in Appendix 1.

\section{Results}

Partial Least Square structural equation modeling (PLS-SEM) was chosen to estimate the conceptual model for its capability to maximize the explained variance of the dependent 
latent variables (Hair et al. 2011). PLS-SEM is particularly suitable for this study, because PLS-SEM has the capability of using path modeling to establish causal relationships; there is no assumption of normal distributions of scale items; and it is a powerful method for collecting data with a relatively small sample size. Recently an increasing number of scholars in tourism have used PLS-SEM (e.g. Escobar-Rodríguez and Carvajal-Trujillo 2014). The software used in this study is Smart PLS 2.0 (Ringle et al. 2005). As suggested by Hair et al. (2011), the t-statistics were computed by using 5000 bootstrap samples with 264 cases. The model estimation followed a two-step approach: measurement models followed by structural model.

\subsection{Measurement model}

All of the item loadings are above the recommended 0.7 and are significant (Hair et al. 2011), the lowest value being 0.793 . The composite reliability (CR) exceeds the recommended threshold of 0.7 (the lowest is 0.853 ), and the average variance extracted (AVE) values are above the recommended level of 0.5 (Hair et al. 2011), with the lowest value of 0.663 (see Appendix 1 for more details).

To confirm the discriminant validity of the latent constructs, cross loadings were examined (see Appendix 2) and square roots of the AVE and latent variables compared (Table 2, Fornell and Larcker 1981). The results show that all of the item loadings on their respective construct are greater than their loadings on other constructs, and the square roots of the AVEs exceed the correlations between every pair of latent variables. Therefore, discriminant validity is established.

[Table 2 about here]

To determine the presence of common method variance bias among the study variables, 
we followed the procedure for PLS suggested by Liang et al. (2007). We created a common method factor in the PLS model by including all the principal constructs' indicators and calculated each indicator's variances substantively explained by the principal construct and by the method. The results were presented in Appendix 3, which show that most method factor loadings are marginally or not significant, and the ratio of average substantive variance $\left(\mathrm{R} 1^{2}=\right.$ $0.718)$ to average method variance $\left(R^{2}=0.007\right)$ is about $103: 1$. Thus, common method bias is unlikely to be a serious concern.

\subsection{Structural model}

Table 3 illustrates the model estimation results, which indicate that the aggregate PLS path coefficients are statistically significant. The value of explained variance $\left(\mathrm{R}^{2}\right)$ for continuance intention is $33 \%$, which is a moderate value (Chin 1998). Blindfolding was run to obtain cross-validated redundancy measures for each construct. These results indicate that all $Q^{2}$ values are larger than zero, suggesting that the exogenous constructs have predictive relevance for the endogenous construct under consideration (Hair et al. 2011).

[Table 3 about here]

The path coefficients for each of the six hypotheses are presented in Table 4 . All the hypotheses are confirmed. Consumer innovativeness has a strong impact on consumer knowledge, supporting H 1. Support was also found for $\mathrm{H} 2 \mathrm{a}$ and $\mathrm{H} 2 \mathrm{~b}$, which suggest the positive relationships between knowledge and the perceptions of ease of use and usefulness. Consistent with $\mathrm{H} 3 \mathrm{a}$ and $\mathrm{H} 3 \mathrm{~b}$, innovativeness was found to have a positive relationship with perceived ease of use and usefulness. Support was found for $\mathrm{H} 4 \mathrm{a}$ and $\mathrm{H} 4 \mathrm{~b}$ too: both perceptions of ease of use and usefulness significantly predict continuance intention, with PU having a stronger predictor power than perceived ease of use. Both user innovativeness and 
user's knowledge have direct effect on continuance intention, although the effect of knowledge is rather weak, supporting $\mathrm{H} 5$ and $\mathrm{H} 6$.

We also examine whether innovativeness and knowledge have an effect on continuance intention mediated through perceived ease of use and PU. The results as shown in Table 4 indicate that both innovativeness and knowledge have direct and total effect on continuance intention, indicating that the effect is partially mediated through perceived ease of use and PU. Among the control variables, although some variables (gender and internet use frequency) have significant effect on continuance intention, their effects are rather marginal.

[Table 4 about here] 


\section{Discussion and Conclusions}

By integrating the TAM with two psychological factors (personal innovativeness and subjective knowledge), this study investigates the model of passenger's continuance intention of online flight check-in technology. By doing so, we fill the research gap regarding the role of psychological factors on continuance intention of online self-service technologies (Kokkinou and Cranage 2013). Moreover, this is one of the first studies that have investigated the influence of TAM factors play on the intention to repeat use after initial adoption of a new technology (Wang et al. 2013).

Findings demonstrate that PU is a strong predictor of continuance intention towards online check-in services, which agrees with a number of previous TAM researches (e.g. Davis 1989; Davis et al. 1989; Keil et al. 1995; Lu et al. 2005).

Interestingly, the importance of the role played by ease of use and usefulness slightly contrasts with a previous study's findings on adoption of kiosks for flight check-in (Lu et al. 2009), where both perceived ease of use and PU explained less than $15 \%$ of variance (they explain $33 \%$ in this study). However, this divergence of findings might be explained by the fact that online flight check-in can be perceived as a more convenient and useful than airport kiosks. For adopting the latter technology, consumers have to drive to the airport, they have to locate kiosks, bring the check-in code with them, and sometimes wait for other people to check-in before being able to do it themselves. Instead online check-in is easier as passengers can do it in the comfort of their home and at the time that best suit them.

This study contributes to the literature by integrating two psychological constructs $-\mathrm{a}$ personality trait (personal innovativeness) and a self-concept (subjective knowledge) to predict continuance intention. Interestingly, passengers' innovativeness and subjective 
knowledge were found to have a direct effect on continuance intention, and an indirect effect through partial mediation of perceived ease of use and PU on continuance intention towards online check-in services. The influence played by passengers' innovativeness on perceived ease of use and usefulness supports the findings of previous studies in other contexts (Lu et al. 2005) but disagree with others who did not find the existence of a relationship between general innovativeness and consumer adoption of technologies (Roehrich 2004; Lu et al. 2005; Liljander et al. 2006; Jackson et al. 2013). The findings of this study contribute to this debate by showing that in the context of online flight check-in and for predicting continuance intention, innovativeness along with subjective knowledge both exert a significant influence on continuance intention both directly and indirectly.

\subsection{Managerial implications}

The findings of this study provide several implications for managers in the transport industries. Managers of transport companies should identify and target innovative passengers and enhance their subjective knowledge perception, so as to encourage repeated usage. In addition to members of online traveler community, the younger members of frequent flyer clubs are often the innovators and early adopters of new technology. For instance, airline companies could develop their own virtual frequent flyer community, which could ease the identification of opinion leaders (generally considered as highly innovative individuals). Once identified, these innovators could be encouraged to keep using the online self-service and spreading the knowledge about its benefits and usefulness through means of incentives such as extra mileage award points every time they book a ticket and check-in online. These incentives could further enhance electronic word of mouth about the PU and ease of use of online flight check-in. Additionally, innovative passengers because of their knowledge of the online self-service technology, could be asked to provide insight of how to improve the online 
flight check-in service.

Furthermore, as subjective knowledge is important for continuance, online service designers could implement some user-support tools to help customers create and disseminate their knowledge, such as 'live-chat' technical support, video demonstration tutorials, and emanuals. In the meantime, airline companies could also encourage innovative customers to produce their own versions of 'user support' contents, for example holding best usergenerated contents awards and videos competition, or set up a monthly top-ten expert users and content contributor award, so as to gather and exploit knowledge of innovative passengers. Finally, the mediating role of perceived usefulness and ease of use indicate that online services design should aim to add more value for the users while simplifying the online service process.

\subsection{Limitations and further research}

Although the results of this study provide new insights, there are several limitations associated with it, which introduce future research opportunities. First, although the sample is quite well spread out demographically it is a self-selected sample of online fliers, which could be considered as a limitation because respondents may be positively biased towards online check-in systems. Future research should sample non-internet users in order to generalize the results of our study.

Second, the study marks one of the first attempts in the transport literature to consider the effect of traveler's innovativeness and subjective knowledge on the continuance intention. Nevertheless, the level of explained variance of our model was moderate, which is probably due to the limited number of antecedent variables included in the model. However, in agreement with Lu et al. (2009) we suggest considering more constructs that could better 
explain passengers' adoption behavior of technologies. For instance, additional psychological antecedents could be used in future research, such as self-concept constructs and other personality traits such as those in the five-factor model (Digman 1990), i.e. openness, conscientiousness, extraversion, agreeableness, and neuroticism.

Third, the context of this study was limited to online flight check-in service. The mixed results obtained in different research call for a comparative study on different types of selfservice technologies (i.e. check-in kiosks, online check-in). Moreover, future research could compare the research model in the contexts of different types of online self-services adopted in transport industries, such as online booking systems.

Fourth, this study employed a cross-section survey; future research might collect longitudinal data which should provide better estimation of how the effects of TAM variables on user behavior change over time. Although one of the merits of the study is to focus on Chinese traveler behavior with online self-services, caution must be exercised in generalizing the results to other populations. Thus, future research may replicate this study in other contexts and with larger sample size. 


\section{References}

Agarwal, Ritu, and Jayesh Prasad. (1998). "A Conceptual and Operational Definition of Personal Innovativeness in the Domain of Information Technology." Information Systems Research, 9 (2): 204-215.

Agarwal, R., Karahanna, E. (2000). Time flies when you're having fun: cognitive absorption and beliefs about information technology usage. MIS Quarterly 24 (4), 665-694.

Álvarez, Leticia Suárez, Ana María Díaz Martín, and Rodolfo Vázquez Casielles. (2007). "Relationship Marketing and Information and Communication Technologies: Analysis of Retail Travel Agencies." Journal of Travel Research, 45 (4): 453-463.

Anderson, Shannon, Lisa Klein Pearo, and Sally K. Widener. (2008). "Drivers of Service Satisfaction: Linking Customer Satisfaction to the Service Concept and Customer Characteristics." Journal of Service Research, 10 (4): 365-381.

Arndt, Johan. (1967). "Role of Product-Related Conversations in the Diffusion of a New Product." Journal of Marketing Research, 4 (3): 291-295.

Ajzen, I., Fishbein, M. (1980). Understanding attitudes and predicting social behavior. Prentice-Hall, Englewood Cliffs, NJ.

Ayeh, Julian K, Norman Au, and Rob Law. (2013). "'Do We Believe in Tripadvisor?' Examining Credibility Perceptions and Online Travelers' Attitude toward Using UserGenerated Content." Journal of Travel Research, 52 (4): 437-452.

Barrutia, Jose M., and Ainhize Gilsanz. (2013). "Electronic Service Quality and Value: Do Consumer Knowledge-Related Resources Matter?" Journal of Service Research, 16 (2): 231-246.

Blodgett, Jeffrey G., Donna J. Hill, and Stephen S. Tax. (1997). "The Effects of Distributive, Procedural, and Interactional Justice on Postcomplaint Behavior." Journal of Retailing, 73 (2): 185-210.

Brucks, Merrie. (1985). "The Effects of Product Class Knowledge on Information Search Behavior." Journal of Consumer Research, 12 (1): 1-16.

Buhalis, Dimitrios. (2004). "Eairlines: Strategic and Tactical Use of Icts in the Airline Industry." Information \& Management, 41 (7): 805-825.

Burson, Katherine A. (2007). "Consumer Product Skill Matching: The Effects of Difficulty on Relative Self-Assessment and Choice." Journal of Consumer Research, 34 (1): 104110.

CARNOC. (2013). "The Arrival of Wechat Era: Over 700,000 China Southern's Passengers Are Using Wechat to Check-in Their Flights." In: China Civil Aviation Resources Network. http://news.carnoc.com/list/267/267322.html (accessed April 28, 2014).

Chau, Patrick Y.K., and Kai. L. Hui. (1998). "Identifying Early Adopters of New It Products: A Case of Windows 95." Information \& Management, 33 (5): 225-230.

Chin, Wynne W. (1998). "The Partial Least Squares Approach to Structural Equation Modeling." Modern Methods for Business Research, 295 (2): 295-336.

CNNIC. (2014). "Statistical Report on Internet Development in China." In: China Internet Network Information Center http://www1.cnnic.cn/ (accessed April 04, 2014).

Cotte, June, and Stacy L Wood. (2004). "Families and Innovative Consumer Behavior: A Triadic Analysis of Sibling and Parental Influence." Journal of Consumer Research, 31 (1): 78-86.

Curran, James M., and Matthew L. Meuter. (2005). "Self-Service Technology Adoption: Comparing Three Technologies." Journal of Services Marketing, 19 (2): 103-113.

Dabholkar, Pratibha A. (1996). "Consumer Evaluations of New Technology-Based SelfService Options: An Investigation of Alternative Models of Service Quality." 
International Journal of Research in Marketing, 13 (1): 29-51.

Davis, Fred D. (1989). "Perceived Usefulness, Perceived Ease of Use, and User Acceptance of Information Technology." MIS Quarterly, 13 (3): 319-340.

Davis, Fred D., Richard P. Bagozzi, and Paul R. Warshaw. (1989). "User Acceptance of Computer Technology: A Comparison of Two Theoretical Models." Management Science, 35 (8): 982-1003.

Digman, John M. (1990). "Personality Structure: Emergence of the Five-Factor Model." Annual Review of Psychology, 41 (1): 417-440.

Engel, James F., Robert J. Kegerreis, and Roger D. Blackwell. (1969). "Word-of-Mouth Communication by the Innovator." Journal of Marketing, 33 (3): 15.

Escobar-Rodríguez, T., and E. Carvajal-Trujillo. (2014). "Online Purchasing Tickets for Low Cost Carriers: An Application of the Unified Theory of Acceptance and Use of Technology (Utaut) Model." Tourism Management, 43 (August): 70-88.

Etgar, Michael. (2008). "A Descriptive Model of the Consumer Co-Production Process." Journal of the Academy of Marketing Science, 36 (1): 97-108.

Feick, Lawrence F., and Linda L. Price. (1987). "The Market Maven: A Diffuser of Marketplace Information." Journal of Marketing, 51 (1): 83-97.

Flynn, Leisa Reinecke, Ronald E Goldsmith, and Jacqueline K Eastman. (1996). "Opinion Leaders and Opinion Seekers: Two New Measurement Scales." Journal of the Academy of Marketing Science, 24 (2): 137-147.

Flynn, Leisa Reinecke, and Ronald E. Goldsmith. (1999). "A Short, Reliable Measure of Subjective Knowledge." Journal of Business Research, 46 (1): 57-66.

Fornell, Claes, and David F. Larcker. (1981). "Evaluating Structural Equation Models with Unobservable Variables and Measurement Error." Journal of Marketing Research, 18 (1): 39-50.

Garg, Rajiv, Michael D Smith, and Rahul Telang. (2011). "Measuring Information Diffusion in an Online Community." Journal of Management Information Systems, 28 (2): 1138.

Gecas, Viktor. (1982). "The Self-Concept." Annual Review of Sociology, 8 (1): 1-33.

Godes, David, and Dina Mayzlin. (2004). "Using Online Conversations to Study Word-ofMouth Communication." Marketing Science, 23 (4): 545-560.

Goldenberg, Jacob, Sangman Han, Donald Lehmann, and Jae Hong. (2009). "The Role of Hubs in the Adoption Processes." Journal of Marketing, 73 (2): 1-13.

Goldsmith, Ronald E., and Charles F. Hofacker. (1991). "Measuring Consumer Innovativeness." Journal of the Academy of Marketing Science, 19 (3): 209-221.

Hair, Joseph F., Christian M Ringle, and Marko Sarstedt. (2011). "Pls-Sem: Indeed a Silver Bullet." The Journal of Marketing Theory and Practice, 19 (2): 139-152.

Hennig-Thurau, Thorsten, Kevin P. Gwinner, Gianfranco Walsh, and Dwayne D. Gremler. (2004). "Electronic Word-of-Mouth Via Consumer-Opinion Platforms: What Motivates Consumers to Articulate Themselves on the Internet?" Journal of Interactive Marketing, 18 (1): 38-52.

Hirschman, Elizabeth C. (1980). "Innovativeness, Novelty Seeking, and Consumer Creativity." Journal of Consumer Research, 7 (3): 283-295.

Hirunyawipada, Tanawat, and Audhesh K Paswan. (2006). "Consumer Innovativeness and Perceived Risk: Implications for High Technology Product Adoption." Journal of Consumer Marketing, 23 (4): 182-198.

IATA. (2015a). " Fast Travel Program" In: International Air Transport Association www.iata.org (accessed March 12, 2015).

IATA. (2015b). "IATA Annual Review." In: International Air Transport Association 
www.iata.org (accessed March 10, 2015).

Im, Subin, Barry L Bayus, and Charlotte H Mason. (2003). "An Empirical Study of Innate Consumer Innovativeness, Personal Characteristics, and New-Product Adoption Behavior." Journal of the Academy of Marketing Science, 31 (1): 61-73.

Karahanna, Elena, Detmar W Straub, and Norman L Chervany. (1999). "Information Technology Adoption across Time: A Cross-Sectional Comparison of Pre-Adoption and Post-Adoption Beliefs." MIS Quarterly, 23 (2): 183-213.

Kokkinou, Alinda, and David A. Cranage. (2013). "Using Self-Service Technology to Reduce Customer Waiting Times." International Journal of Hospitality Management, 33 (June): 435-445.

Keil, M., Beranek, P.M., Konsynski, B.R., 1995. Usefulness and ease of use: field study evidence regarding task considerations. Decision Support Systems, 13, 75-91.

Klerck, D., \& Sweeney, J. C. (2007). The effect of knowledge types on consumer-perceived risk and adoption of genetically modified foods. Psychology and Marketing, 24(2), 171-193.

Jackson, J. D., Mun, Y. Y., \& Park, J. S. (2013). An empirical test of three mediation models for the relationship between personal innovativeness and user acceptance of technology. Information \& Management, 50(4), 154-161.

Lassar, Walfried M, Chris Manolis, and Sharon S Lassar. (2005). "The Relationship between Consumer Innovativeness, Personal Characteristics, and Online Banking Adoption." International Journal of Bank Marketing, 23 (2): 176-199.

Lee, Yi-Hsuan, Yi-Chuan Hsieh, and Chia-Ning Hsu. (2011). "Adding Innovation Diffusion Theory to the Technology Acceptance Model: Supporting Employees' Intentions to Use E-Learning Systems." Educational Technology \& Society, 14 (4): 124-137.

Liang, Huigang, Nilesh Saraf, Qing Hu, and Yajiong Xue. (2007). "Assimilation of Enterprise Systems: The Effect of Institutional Pressures and the Mediating Role of Top Management." MIS Quarterly, 31 (1): 59-87.

Liljander, Veronica, Filippa Gillberg, Johanna Gummerus, and Allard van Riel. (2006). "Technology Readiness and the Evaluation and Adoption of Self-Service Technologies." Journal of Retailing and Consumer Services, 13 (3): 177-191.

Lu, Jin-Long Chou, Hung-Yen, Ling, Pei-Chuan (2009). "Investigating passengers' intentions to use technology-based self check-in services". Transportation Research Part E: Logistics and Transportation Review, 45(2): 345-356.

Lu, J., Yao, J.E., Yu, C.-S., (2005). Personal inn`ovativeness, social influences and adoption of wireless internet services via mobile technology. Journal of Strategic Information Systems 14 (3), 245-268.

Markus, Hazel, and Elissa Wurf. (1987). "The Dynamic Self-Concept: A Social Psychological Perspective." Annual Review of Psychology, 38 (1): 299-337.

Marsh, Herbert W. (1986). "Global Self-Esteem: Its Relation to Specific Facets of SelfConcept and Their Importance." Journal of Personality and Social Psychology, 51 (6): 1224-1236.

Meuter, Matthew L, Mary Jo Bitner, Amy L Ostrom, and Stephen W Brown. (2005). "Choosing among Alternative Service Delivery Modes: An Investigation of Customer Trial of Self-Service Technologies." Journal of Marketing, 69 (2): 61-83.

Meuter, Matthew L., Amy L. Ostrom, Robert I. Roundtree, and Mary Jo Bitner. (2000). "SelfService Technologies: Understanding Customer Satisfaction with Technology-Based Service Encounters." Journal of Marketing, 64 (3): 50-64.

Midgley, David F, and Grahame R Dowling. (1978). "Innovativeness: The Concept and Its Measurement." Journal of Consumer Research, 4 (4): 229-242. 
Moore, Gary C., and Izak Benbasat. (1991). "Development of an Instrument to Measure the Perceptions of Adopting an Information Technology Innovation." Information Systems Research, 2 (3): 192-222.

Moorman, Christine, Kristin Diehl, David Brinberg, and Blair Kidwell. (2004). "Subjective Knowledge, Search Locations, and Consumer Choice." Journal of Consumer Research, 31 (3): 673-680.

Myers, David G., and Jean M. Twenge. (2013). Social Psychology. 11th ed. New York, NY: McGraw-Hill.

Packard, Grant, and David B. Wooten. (2013). "Compensatory Knowledge Signaling in Consumer Word-of-Mouth." Journal of Consumer Psychology, 23 (4): 434-450.

Park, C. Whan, David L. Mothersbaugh, and Lawrence Feick. (1994). "Consumer Knowledge Assessment." Journal of Consumer Research, 21 (1): 71-82.

Park, Young A, and Ulrike Gretzel. (2007). "Success Factors for Destination Marketing Web Sites: A Qualitative Meta-Analysis." Journal of Travel Research, 46 (1): 46-63.

Pervin, Lawrence A. (2003). The Science of Personality. New York: Oxford University Press. Phares, E Jerry. (1991). Introduction to Psychology. New York: Harper Collins Publishers.

Pikkarainen, Tero, Kari Pikkarainen, Heikki Karjaluoto, and Seppo Pahnila. (2004). "Consumer Acceptance of Online Banking: An Extension of the Technology Acceptance Model." Internet Research, 14 (3): 224-235.

Ringle, Christian Marc, Sven Wende, and Alexander Will. (2005). "Smartpls 2.0 (M3) " In. Hamburg SmartPLS. http://www.smartpls.de (accessed July 20, 2014).

Roehrich, Gilles. (2004). "Consumer Innovativeness: Concepts and Measurements." Journal of Business Research, 57 (6): 671-677.

Rogers, Everett M. (1995). Diffusion of Innovations. New York: Free Press.

Shamir, Boas, Robert J. House, and Michael B. Arthur. (1993). "The Motivational Effects of Charismatic Leadership: A Self-Concept Based Theory." Organization Science, 4 (4): 577-594.

Sirgy, M.J. (1982). "Self-concept in consumer behavior: a critical review", Journal of Consumer Research, 9 (3): 287-300.

Steenkamp, Jan-Benedict E.M., Frenkel ter Hofstede, and Michel Wedel. (1999). "A CrossNational Investigation into the Individual and National Cultural Antecedents of Consumer Innovativeness." Journal of Marketing, 63 (2): 55-69.

Stockdale, Rosemary. (2007). "Managing Customer Relationships in the Self-Service Environment of E-Tourism." Journal of Vacation Marketing, 13 (3): 205-219.

Sun, Tao, Seounmi Youn, Guohua Wu, and Mana Kuntaraporn. (2006). "Online Word-ofMouth (or Mouse): An Exploration of Its Antecedents and Consequences." Journal of Computer-Mediated Communication, 11 (4): 1104-1127.

Tafarodi, Romin W, and William B Swann. (1995). "Self-Linking and Self-Competence as Dimensions of Global Self-Esteem: Initial Validation of a Measure." Journal of Personality Assessment, 65 (2): 322-342.

Tanford, Sarah, Seyhmus Baloglu, and Mehmet Erdem. (2012). "Travel Packaging on the Internet the Impact of Pricing Information and Perceived Value on Consumer Choice." Journal of Travel Research, 51 (1): 68-80.

Thatcher, Jason Bennett, and Pamela L. Perrewe. (2002). "An Empirical Examination of Individual Traits as Antecedents to Computer Anxiety and Computer Self-Efficacy." MIS Quarterly, 26 (4): 381-396.

Venkatesh, Viswanath, Michael G Morris, Gordon B Davis, and Fred D Davis. (2003). "User Acceptance of Information Technology: Toward a Unified View." MIS Quarterly, 27 (3): 425-478. 
Wang, Cheng, Jennifer Harris, and Paul Patterson. (2013). "The Roles of Habit, Self-Efficacy, and Satisfaction in Driving Continued Use of Self-Service Technologies: A Longitudinal Study." Journal of Service Research, 11 (4): 407-428

Wasko, Molly McLure, and Samer Faraj. (2005). "Why Should I Share? Examining Social Capital and Knowledge Contribution in Electronic Networks of Practice." MIS Quarterly, 29 (1): 35-57.

Wu, Jen-Her, and Shu-Ching Wang. (2005). "What Drives Mobile Commerce?: An Empirical Evaluation of the Revised Technology Acceptance Model." Information \& Management, 42 (5): 719-729.

Xiang, Zheng, and Ulrike Gretzel. (2010). "Role of Social Media in Online Travel Information Search." Tourism Management, 31 (2): 179-188.

Young, H. Peyton. (2009). "Innovation Diffusion in Heterogeneous Populations: Contagion, Social Influence, and Social Learning." The American Economic Review, 99 (5): 1899-1924. 


\section{Tables}

Table 1. Profile of respondents

\begin{tabular}{|c|c|c|}
\hline & Frequency & Percentage $(\%)$ \\
\hline \multicolumn{3}{|l|}{ Age } \\
\hline $18-29$ & 27 & 10.2 \\
\hline 30 to 39 & 154 & 58.3 \\
\hline 40 to 49 & 46 & 17.4 \\
\hline 50 to 59 & 31 & 11.7 \\
\hline 60 and over & 6 & 2.3 \\
\hline \multicolumn{3}{|l|}{ Gender } \\
\hline Female & 141 & 53.4 \\
\hline Male & 123 & 46.6 \\
\hline \multicolumn{3}{|l|}{ Education } \\
\hline Up to secondary school & 67 & 25.4 \\
\hline Bachelor degree & 137 & 51.9 \\
\hline Postgraduate degree and above & 60 & 22.7 \\
\hline \multicolumn{3}{|l|}{ Annual Income (CNY10,000) } \\
\hline Less than 5 & 90 & 34.1 \\
\hline $5-10$ & 66 & 25.0 \\
\hline $11-15$ & 40 & 15.2 \\
\hline $16-20$ & 26 & 9.8 \\
\hline $21-25$ & 26 & 9.8 \\
\hline 26 and above & 16 & 6.1 \\
\hline \multicolumn{3}{|l|}{ Occupation } \\
\hline Office worker & 26 & 9.8 \\
\hline Civil servant & 43 & 16.3 \\
\hline Professional & 56 & 21.2 \\
\hline Businessperson & 80 & 30.3 \\
\hline Service worker & 8 & 3 \\
\hline Homemaker & 1 & 0.4 \\
\hline Student & 38 & 14.4 \\
\hline Others & 12 & 4.5 \\
\hline \multicolumn{3}{|l|}{ Internet use frequency } \\
\hline A few times in a month or less & 10 & 3.8 \\
\hline A few times in a week & 50 & 18.9 \\
\hline About once a day & 60 & 22.7 \\
\hline Several times on each day & 144 & 54.5 \\
\hline
\end{tabular}


Table 2. Construct Correlations \& Square Roots of AVE

\begin{tabular}{cccccc}
\hline & KN & IN & PEOU & PU & CI \\
\hline KN & $\mathbf{0 . 8 3 1}$ & & & & \\
IN & 0.512 & $\mathbf{0 . 8 1 8}$ & & & \\
PEOU & 0.433 & 0.412 & $\mathbf{0 . 8 1 4}$ & & \\
PU & 0.512 & 0.403 & 0.508 & $\mathbf{0 . 8 4 7}$ & \\
CI & 0.387 & 0.380 & 0.402 & 0.512 & $\mathbf{0 . 8 8 4}$ \\
& & & & & \\
\hline
\end{tabular}

Notes: Boldface numbers on the diagonal are the square root of the average variance extracted. $\mathrm{KN}=$ Subjective Knowledge, $\mathrm{IN}=$ Global Innovativeness, $\mathrm{PEOU}=$ Perceived Ease of Use, $\mathrm{PU}$ $=$ Perceived Usefulness, $\mathrm{CI}=$ Continuance intention. 
Table 3. Results of Hypothesis Testing

\begin{tabular}{llll}
\hline Hypotheses & Path & Coefficient & Supported? \\
\hline H 1 & Innovativeness $\rightarrow$ Subjective Knowledge & $0.512^{* *}$ & Yes \\
H 2a & Subjective Knowledge $\rightarrow$ Perceived ease of use & $0.302^{* *}$ & Yes \\
H 2b & Subjective Knowledge $\rightarrow$ Perceived usefulness & $0.190^{* *}$ & Yes \\
H 3a & Innovativeness $\rightarrow$ Perceived ease of use & $0.258^{* *}$ & Yes \\
H 3b & Innovativeness $\rightarrow$ Perceived usefulness & $0.416^{* *}$ & Yes \\
H 4a & Perceived ease of use $\rightarrow$ Continuance intention & $0.140^{* *}$ & Yes \\
H 4b & Perceived usefulness $\rightarrow$ Continuance intention & $0.335^{* *}$ & Yes \\
H 5 & Innovativeness $\rightarrow$ Continuance intention & $0.147^{* *}$ & Yes \\
H 6 & Subjective Knowledge $\rightarrow$ Continuance & $0.079 *$ & Yes (weakly) \\
& intention & & \\
\hline
\end{tabular}

Note: $* p<.05 ; * * p<.01$ 
Table 4. Total effect

\begin{tabular}{lrc} 
& \multicolumn{1}{l}{ CI } & \\
& Direct & Total \\
\hline IN & $0.147^{* *}$ & $0.380^{* *}$ \\
KN & $0.079^{* *}$ & $0.261^{* *}$ \\
PEOU & $0.140^{* *}$ & \\
PU & $0.335^{* *}$ &
\end{tabular}

Control variables

$\begin{array}{ll}\text { Age } & 0.002 \\ \text { Gender } & 0.074^{*} \\ \text { Education } & -0.037 \\ \text { Income } & -0.012 \\ \text { Internet use frequency } & -0.066^{*}\end{array}$

Note: $* p<.05 ; * * p<.01 ; \quad \mathrm{IN}=$ Global Innovativeness, $\mathrm{KN}=$ Subjective Knowledge, PEOU = Perceived Ease of Use, $\mathrm{PU}=$ Perceived Usefulness, $\mathrm{CI}=$ Continuance intention . 
Figure 1.

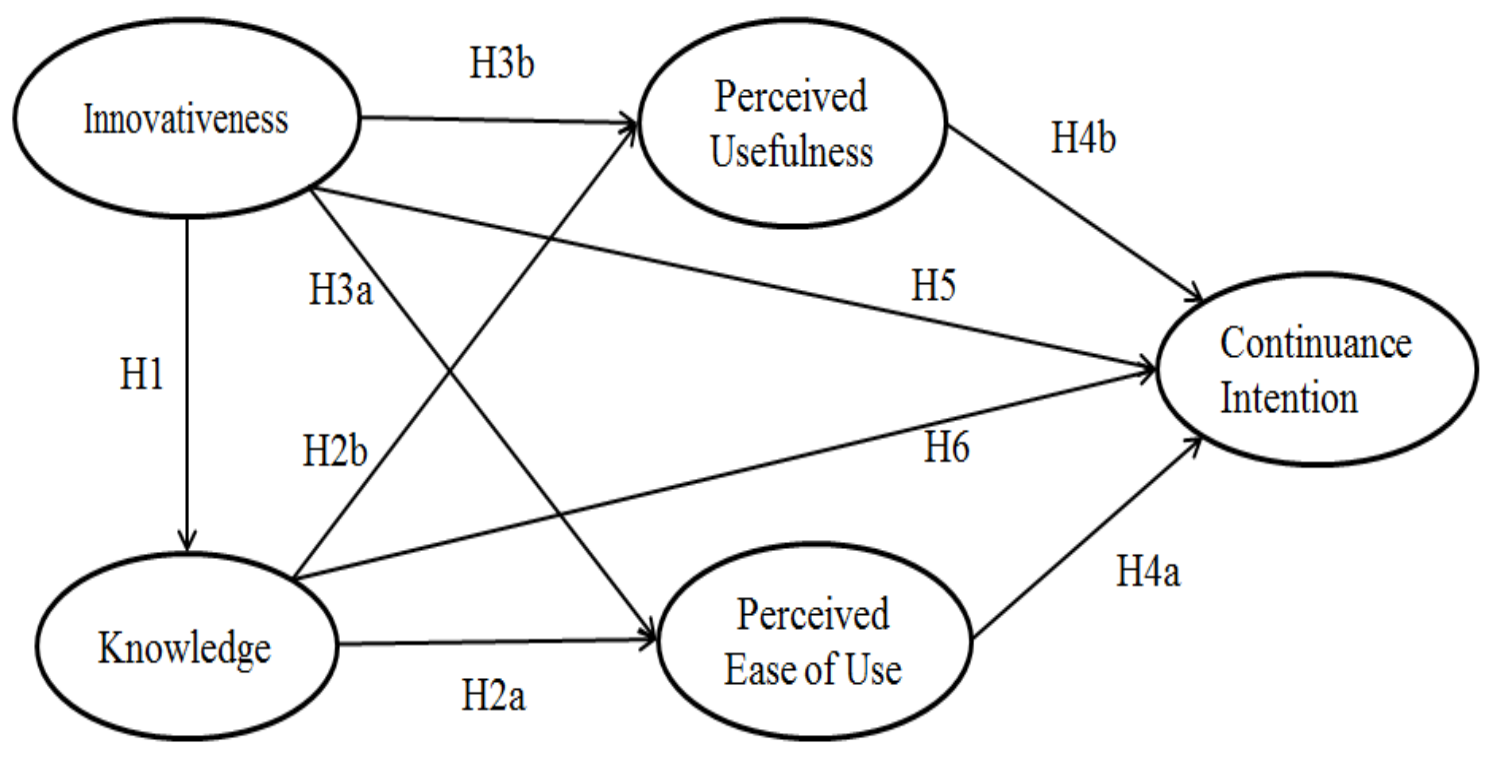

Figure 1. Conceptual model 


\section{Appendices}

Appendix 1. Scale Items \& Convergent Validity

Constructs/Items (5-point scales)

Loading

Personal innovativeness $(\mathrm{IN}, \mathrm{CR}=0.858 ; \mathrm{AVE}=0.669)$

IN1 I like to experiment with new ways of doing things.

IN2 I like to try new products.

IN3 I am among the first in my circle of friends to use new technologies

Subjective Knowledge $(\mathrm{KN}, \mathrm{CR}=0.870 ; \mathrm{AVE}=0.690)$

KN1 I know pretty much about airline websites.

KN2 I am an expert user of online check-in service

KN3 I know pretty much about how to use online check-in service

Perceived ease of use ( $\mathrm{PEOU}, \mathrm{CR}=0.853 ; \mathrm{AVE}=0.663)$

PEOU1 Online check-in requires little effort.

PEOU2 The process of online check-in is clear.

PEOU3 Online check-in operation is simple and easy to understand.

0.649

Perceived usefulness $(\mathrm{PU}, \mathrm{CR}=0.884 ; \mathrm{AVE}=0.717)$

PU1 It saves me time for not having to queue at the airport.

PU2 It is useful for selecting the seat I prefer.

PU3 It is useful, as I can either print out boarding pass or have it on my smartphone.

Continuance intention $(\mathrm{CI}, \mathrm{CR}=0.878 ; \mathrm{AVE}=0.782)$

CI1 I would use online check-in service next time I travel.

CI2 It is likely that I will use online check-in service again.

0.896 Notes: $* * p<.01 ; \mathrm{CR}=$ composite reliability, $\mathrm{AVE}=$ Average variance extracted. 
Appendix 2. Cross Loadings

\begin{tabular}{ccllll}
\hline & KN & IN & PEOU & PU & CI \\
\hline KN1 & $\mathbf{0 . 8 2 0}$ & 0.394 & 0.339 & 0.392 & 0.335 \\
KN2 & $\mathbf{0 . 8 4 9}$ & 0.431 & 0.361 & 0.416 & 0.301 \\
KN3 & $\mathbf{0 . 8 2 3}$ & 0.448 & 0.379 & 0.467 & 0.328 \\
IN1 & 0.383 & $\mathbf{0 . 7 9 3}$ & 0.235 & 0.298 & 0.315 \\
IN2 & 0.448 & $\mathbf{0 . 8 2 0}$ & 0.311 & 0.289 & 0.294 \\
IN3 & 0.425 & $\mathbf{0 . 8 4 0}$ & 0.446 & 0.391 & 0.323 \\
PEOU1 & 0.314 & 0.325 & $\mathbf{0 . 8 5 3}$ & 0.369 & 0.279 \\
PEOU2 & 0.407 & 0.447 & $\mathbf{0 . 9 1 7}$ & 0.496 & 0.441 \\
PEOU3 & 0.334 & 0.175 & $\mathbf{0 . 6 4 9}$ & 0.355 & 0.212 \\
PU1 & 0.453 & 0.357 & 0.430 & $\mathbf{0 . 8 6 4}$ & 0.44 \\
PU2 & 0.396 & 0.289 & 0.429 & $\mathbf{0 . 8 4 5}$ & 0.36 \\
PU3 & 0.445 & 0.367 & 0.431 & $\mathbf{0 . 8 3 1}$ & 0.486 \\
CI1 & 0.383 & 0.376 & 0.328 & 0.410 & $\mathbf{0 . 8 7 3}$ \\
CI2 & 0.305 & 0.300 & 0.381 & 0.493 & $\mathbf{0 . 8 9 6}$ \\
\hline
\end{tabular}

Notes: Boldface numbers are loadings of indicators to their own construct; other numbers are the cross loadings. $\mathrm{KN}=$ Subjective Knowledge, $\mathrm{IN}=$ Global Innovativeness, $\mathrm{PEOU}=$ Perceived Ease of Use, PU = Perceived Usefulness, $\mathrm{CI}=$ Continuance intention. 
Appendix 3. Common Method Variance Test

\begin{tabular}{llclll}
\hline Construct & Indicator & $\begin{array}{l}\text { Substantive } \\
\text { Factor Loading } \\
\text { (R1) }\end{array}$ & R1 & $\begin{array}{l}\text { Method } \\
\text { Factor Loading } \\
\text { (R2) }\end{array}$ & R2 \\
\hline Innovativeness & IN1 & $0.849^{* *}$ & 0.721 & $-0.065^{* *}$ & 0.004 \\
& IN2 & $0.865^{* *}$ & 0.748 & $-0.051^{*}$ & 0.003 \\
Subjective Knowledge & KN3 & $0.745^{* *}$ & 0.555 & $0.110^{* *}$ & 0.012 \\
& KN2 & $0.854^{* *}$ & 0.729 & -0.038 & 0.001 \\
& KN3 & $0.877^{* *}$ & 0.769 & -0.033 & 0.001 \\
Perceived ease of use & PEOU1 & $0.761^{* *}$ & 0.579 & $0.071^{* *}$ & 0.005 \\
& PEOU2 & $0.785^{* *}$ & 0.616 & $0.150^{* *}$ & 0.023 \\
& PEOU3 & $0.730^{* *}$ & 0.533 & -0.080 & 0.006 \\
Perceived usefulness & PU1 & $0.849^{* *}$ & 0.721 & 0.023 & 0.001 \\
& PU2 & $0.967^{* *}$ & 0.935 & $-0.131^{* *}$ & 0.017 \\
& PU3 & $0.725^{* *}$ & 0.526 & $0.109 * *$ & 0.012 \\
Continuance intention & CI1 & $0.874^{* *}$ & 0.764 & 0.014 & 0.000 \\
& CI2 & $0.895^{* *}$ & 0.801 & -0.014 & 0.000 \\
& & $\mathbf{0 . 8 4 4}$ & $\mathbf{0 . 7 1 8}$ & $\mathbf{- 0 . 0 0 2}$ & $\mathbf{0 . 0 0 7}$ \\
\hline
\end{tabular}

Notes: $* p<.05 ; * * p<.01 ; \mathrm{KN}=$ Subjective Knowledge, $\mathrm{IN}=$ Global Innovativeness, PEOU = Perceived Ease of Use, $\mathrm{PU}=$ Perceived Usefulness, $\mathrm{CI}=$ Continuance intention. 